Check for updates

Cite this: RSC Adv., 2019, 9, 4925

Received 22nd December 2018 Accepted 22nd January 2019

DOI: 10.1039/c8ra10497b

rsc.li/rsc-advances

\section{Nitrogen-decorated, porous carbons derived from waste cow manure as efficient catalysts for the selective capture and conversion of $\mathrm{CO}_{2} \dagger$}

\begin{abstract}
Weiping Kong (iD) and Jing Liu
The catalytic conversion of $\mathrm{CO}_{2}$ is a promising solution to the greenhouse effect and simultaneously recycles the carbon sources to produce high value-added chemicals. Herein, we demonstrated a class of nanoporous carbons, which were synthesized by the direct carbonization of bio-waste cow manure, followed by activation with $\mathrm{KOH}$ and $\mathrm{NaNH}_{2}$. Various characterizations indicate that the resultant nanoporous carbons have abundant nanopores and nitrogen sites. As a result, their performances for the capture and catalytic conversion of $\mathrm{CO}_{2}$ were investigated. The synthesized nanoporous carbons exhibited superior properties for the selective capture and catalytic cycloaddition of $\mathrm{CO}_{2}$ to propylene oxide as compared to various solid materials.
\end{abstract}

\section{Introduction}

Energy harvesting processes, especially the combustion of fossil fuels and industrial hydrogen production, produce large amounts of $\mathrm{CO}_{2} \cdot{ }^{1,2} \mathrm{CO}_{2}$ emitted into the atmosphere severely disrupts the natural carbon cycle; this has resulted in a significant increase in the $\mathrm{CO}_{2}$ concentration in the atmosphere over the past century. ${ }^{3}$ The excess $\mathrm{CO}_{2}$ accumulated in the atmosphere would prevent the radiation of heat from the surface of earth to the space. This may be a disaster for the environment and eco-system on the earth because it would cause an increase in temperature on the earth and accelerate the rising of the sea level and desertification of land. ${ }^{3}$ Controlling the emission of $\mathrm{CO}_{2}$ from industrial activities has therefore become an urgent mission for scientists across the world. ${ }^{4}$ On the other hand, $\mathrm{CO}_{2}$ is an important source of carbon for the construction of a variety of fine chemicals such as cyclic carbonates, urea derivatives, carboxylic acids, and formamides. ${ }^{5-7}$ Among the available routes for $\mathrm{CO}_{2}$ conversion, the production of cyclic carbonates is particularly attractive owing to the $100 \%$ atom efficiency of the cycloaddition of $\mathrm{CO}_{2}$ to epoxides. ${ }^{8}$ The obtained cyclic carbonates can be used as low-volatile aprotic polar solvents, fine chemical intermediates, precursors of polymeric materials, and even electrolytes for lithium-ion batteries. ${ }^{5}$ Therefore, the simultaneous capture and conversion of $\mathrm{CO}_{2}$ has been proposed as an effective solution to the $\mathrm{CO}_{2}$ emissionrelated issues currently confronting human beings. ${ }^{7}$

Due to the thermodynamically stable nature of $\mathrm{CO}_{2}$, advanced catalysts are required to promote the conversion of

School of Teacher Education, Shaoxing University, Shaoxing, Zhejiang Province, 312000, China. E-mail: kongweiping0111@163.com

$\dagger$ Electronic supplementary information (ESI) available. See DOI: $10.1039 / \mathrm{c} 8 \mathrm{ra} 10497 \mathrm{~b}$
$\mathrm{CO}_{2}$ under mild conditions. To date, many kinds of catalysts, including homogeneous and heterogeneous catalysts, have been developed for the catalytic conversion of $\mathrm{CO}_{2}$. Typical homogeneous catalysts designated for $\mathrm{CO}_{2}$ conversion are metal complexes, ${ }^{9}$ ionic liquids (ILs), ${ }^{10} \mathrm{~N}$-heterocyclic carbenes (NHCs),${ }^{11}$ superbases ${ }^{12}$ and frustrated Lewis pairs (FLPs). ${ }^{13}$ Typical heterogeneous catalysts designated for $\mathrm{CO}_{2}$ conversion are porous carbons, ${ }^{14-16}$ porous silicas, ${ }^{17}$ zeolites, ${ }^{18}$ metalorganic frameworks (MOFs), ${ }^{19}$ and porous organic polymers (POPs). ${ }^{20-22}$ Compared to these homogeneous catalysts, the heterogeneous catalysts are more preferred due to their facile recycling. Particularly, porous carbon materials are believed to be one of the most promising platforms for the fabrication of heterogeneous catalysts for $\mathrm{CO}_{2}$ conversion because they have many unique features such as low cost, large surface area, high thermal stability and strong hydrophobicity. ${ }^{23,24}$ In this respect, some progresses have been made. For example, Cao et al. synthesized a N-doped porous carbon monolith as a heterogeneous catalyst from alginic acid in the presence of pyrrole, ethylenediamine and glutaraldehyde for the production of chloropropene carbonate from $\mathrm{CO}_{2}$ and epichlorohydrin. ${ }^{14} \mathrm{Hu}$ et al. synthesized $\mathrm{N}$-doped porous carbon nanofiber webs from pre-synthesized polypyrrole nanofiber webs as a heterogeneous catalyst for the production of cyclic carbonates from $\mathrm{CO}_{2}$ and epoxides. ${ }^{15}$ Overall, many kinds of N-doped porous materials have been fabricated, which have been successfully employed as heterogeneous catalysts or supports for the production of cyclic carbonates from $\mathrm{CO}_{2}$ and epoxides. ${ }^{16}$

Recently, a lot of interest has been paid to the transformation of bio-waste into carbon materials with the aim to reduce the production cost of carbon materials and improve the utilization of bio-waste. For example, studies have been reported on the synthesis of carbon materials from microalgae residue,${ }^{25}$ corn straw, ${ }^{26}$ banana peel, ${ }^{27}$ leaves, ${ }^{28}$ etc. The 
development of modern green and sustainable chemistry has also emphasized the advantages of using bio-waste for the production of value-added materials. In this study, we report the synthesis of porous carbon materials from cow manure, which is quite abundant in local farms and used for the preparation of carbon quantum dots. ${ }^{29}$ Fresh cow manure contains a variety of organic and inorganic matter such as protein, fat, fiber and salts. Although cow manure can be used for the production of organic fertilizers, its utilization is still insufficient. The environmental pollution caused by the disposal of cow manure is a significant issue in rural areas. To date, there are very few studies on the use of cow manure for the synthesis of advanced materials. ${ }^{30}$ Herein, porous carbon materials were synthesized by the direct carbonization of cow manure followed by chemical activation. The synthesized cow manure-derived carbons (CMCs) have a BET surface area as high as $1106 \mathrm{~m}^{2}$ $\mathrm{g}^{-1}$, hierarchical nanoporosity, and nitrogen sites with abundant pyridinic characteristics successfully doped into their networks. As a result, the CMCs display competitive performance in the selective capture of $\mathrm{CO}_{2}$. More interestingly, the synthesized CMCs also display excellent performance for the catalytic cycloaddition of $\mathrm{CO}_{2}$ to epoxides after metallization. This study describes a facile transformation of bio-waste into $\mathrm{N}$ doped porous carbons, which have been successfully used in the selective capture and conversion of $\mathrm{CO}_{2}$; this promotes the widespread application of $\mathrm{N}$-doped porous carbons in various research fields.

\section{Experimental}

\subsection{Chemicals}

Fresh cow manure was obtained from local farms. It was dried at $120^{\circ} \mathrm{C}$ for $12 \mathrm{~h}$ before use. $\mathrm{CO}_{2}(99.99 \mathrm{v} / \mathrm{v} \%)$ and $\mathrm{N}_{2}(99.99 \mathrm{v} / \mathrm{v} \%)$ were supplied by APK Gas Co. Ltd., China. $\mathrm{KOH}, \mathrm{NaNH}_{2}$, $\mathrm{CoCl}_{2} \cdot 6 \mathrm{H}_{2} \mathrm{O}, \mathrm{Zn}(\mathrm{OAc})_{2} \cdot 2 \mathrm{H}_{2} \mathrm{O}$, propylene oxide (PO) and tetrabutylammonium bromide (TBAB) were supplied by Sinopharm Chemical Reagent Co. Ltd., China. All chemicals were of analytical grade and used as received without further purification.

\subsection{Synthesis}

Typically, $10.0 \mathrm{~g}$ of dried cow manure was loaded into a tube furnace, heated to $800{ }^{\circ} \mathrm{C}$ at the rate of $10{ }^{\circ} \mathrm{C} \mathrm{min}{ }^{-1}$ under the protection of $\mathrm{N}_{2}$, and maintained at the target temperature for $4 \mathrm{~h}$. After being naturally cooled down to room temperature, the obtained head-product was obtained with the yield of $42.1 \%$ and denoted as CMC.

The CMC was then subjected to chemical activation to increase its porosity. Herein, two different chemical activation agents ( $\mathrm{KOH}$ and $\left.\mathrm{NaNH}_{2}\right)$ were used. In a typical run, $1 \mathrm{~g}$ of CMC and $3 \mathrm{~g}$ of chemical activation agent were mixed thoroughly, loaded into a tube furnace, heated to $600{ }^{\circ} \mathrm{C}$ at the rate of $10{ }^{\circ} \mathrm{C} \min ^{-1}$ under the protection of $\mathrm{N}_{2}$, and maintained at the target temperature for $1 \mathrm{~h}$ (as shown in Scheme 1). After being naturally cooled down to room temperature, the activated CMC was obtained with a yield of $37.8 \%$. The final products were denoted as CMC-A-1 (when the chemical activation agent was $\mathrm{KOH}$ ) and CMC-A-2 (when the chemical activation agent was $\mathrm{NaNH}_{2}$ ).

The CMC-based catalysts were prepared by supporting $\mathrm{Co}^{2+}$ or $\mathrm{Zn}^{2+}$ on the surface of the activated CMC. In a typical run, $0.80 \mathrm{~g}$ of CMC-A-1 and $0.81 \mathrm{~g}$ of $\mathrm{CoCl}_{2} \cdot 6 \mathrm{H}_{2} \mathrm{O}$ were added to $150 \mathrm{~mL}$ of degassed DMF, and the mixture was vigorously stirred at $120{ }^{\circ} \mathrm{C}$ under the protection of $\mathrm{N}_{2}$ for $12 \mathrm{~h}$. The resultant solid was separated by filtration and washed thoroughly with hot DMF. After drying at $60{ }^{\circ} \mathrm{C}$ and $0.1 \mathrm{kPa}$ for $48 \mathrm{~h}$, Co@CMC-A1 was obtained with a yield of $82.6 \%$. The final contents of the metal ions in the CMC-based catalysts were determined by ICP.

\subsection{Characterization}

Before characterization, the samples were pretreated at $200{ }^{\circ} \mathrm{C}$ with a $\mathrm{N}_{2}$ flow for $12 \mathrm{~h}$. The $\mathrm{N}_{2}$ adsorption isotherms were obtained at $-196{ }^{\circ} \mathrm{C}$ using the Micromeritics Tristar II 3020 system to determine the textural properties. The specific surface areas were calculated using the BET equation in the relative pressure range of $0.05-0.2$. The micropore volumes were estimated by the $t$-plot method in the thickness range of $0.45-0.6 \mathrm{~nm}$. The total pore volumes were estimated from the amount of $\mathrm{N}_{2}$ adsorbed at the relative pressure of 0.97 . The pore size distributions were calculated using the BJH model. Elemental analysis was performed using the Elementar Vario EL II system. The SEM images were obtained using the Zeiss Auriga Crossbeam electron microscope at an acceleration voltage of $5 \mathrm{kV}$. The TEM images were obtained using the JEOL JEM-2100F field-induced electron microscope at an acceleration voltage of $200 \mathrm{kV}$. The
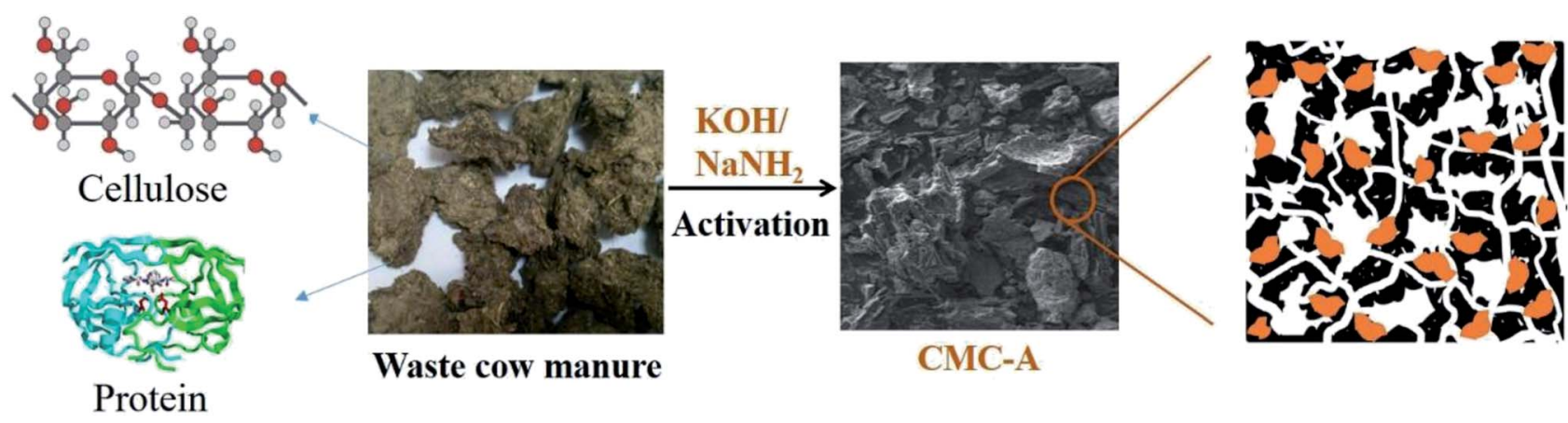

Scheme 1 Synthetic processes of CMC-A. 

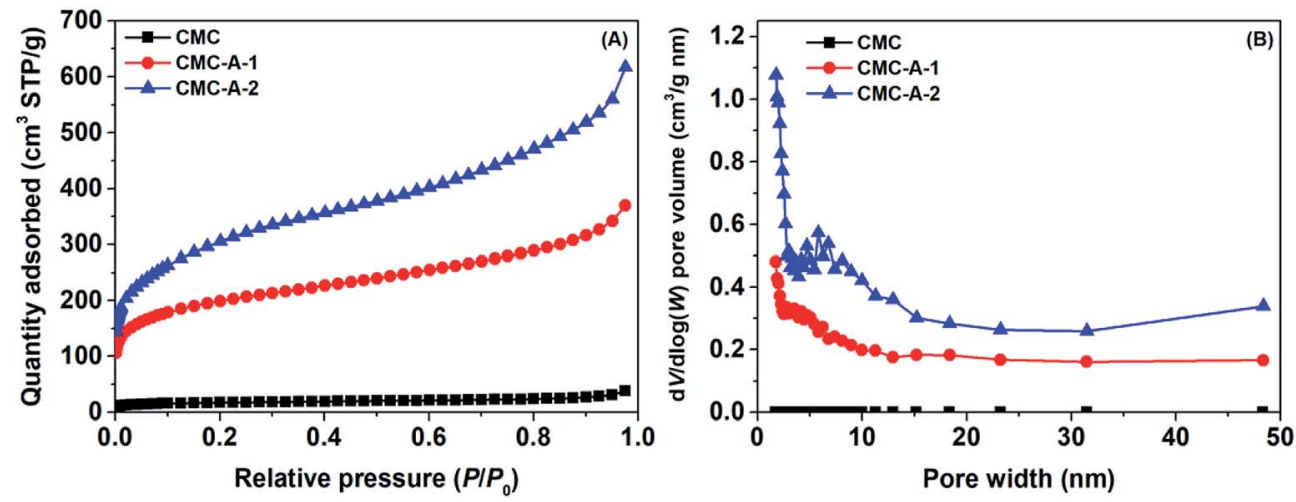

Fig. $1 \mathrm{~N}_{2}$ adsorption isotherms at $-196{ }^{\circ} \mathrm{C}(\mathrm{A})$ and pore width distributions (B) of CMCs.

XRD patterns were obtained via the PANalytical powder diffractometer using $\mathrm{Cu} \mathrm{K} \alpha$ radiation at a voltage of $40 \mathrm{kV}$ and current of $40 \mathrm{~mA}$. Raman spectra were obtained using the Princeton Acton TriVista 555 spectrometer with $\lambda=532 \mathrm{~nm}$ laser excitation. The XPS spectra were obtained using the Thermo Scientific EscaLab 250Xi spectrometer with Al-K $\alpha$ radiation, and the binding energies were calibrated using the C1s peak at $284.9 \mathrm{eV}$. The ICP analysis was performed using the Jarrel-AshJ-A1100 spectrometer.

\subsection{Gas adsorption}

Before measurements, the samples were pretreated at $200{ }^{\circ} \mathrm{C}$ with a $\mathrm{N}_{2}$ flow for $12 \mathrm{~h}$. The $\mathrm{CO}_{2}$ and $\mathrm{N}_{2}$ adsorption isotherms at 0 and $23{ }^{\circ} \mathrm{C}$ were obtained using the same Micromeritics Tristar II 3020 system.

\section{$2.5 \mathrm{CO}_{2}$ conversion}

The reaction was performed in a stainless steel autoclave with a Teflon tube (inner volume: $25 \mathrm{~mL}$ ). The reactor was purged with $\mathrm{CO}_{2}$ to evacuate the air and maintained at $0{ }^{\circ} \mathrm{C}$ for $10 \mathrm{~min}$. In a typical run, $20 \mathrm{mmol}$ of $\mathrm{PO}, 1.44 \mathrm{mmol}$ of TBAB and $30 \mathrm{mg}$ of catalyst were quickly loaded into the reactor. $\mathrm{As}_{\mathrm{CO}_{2}}$ was charged to 1.5 MPa, the autoclave was sealed, and the reactants were stirred at $100{ }^{\circ} \mathrm{C}$ for $1.5 \mathrm{~h}$. After the completion of the reaction, the excess $\mathrm{CO}_{2}$ was vented at $0{ }^{\circ} \mathrm{C}$. The yields of the products were determined by the Agilent $7890 \mathrm{~A}$ chromatograph equipped with a flame ionization detector (FID). For catalyst recycling, the catalyst was separated by filtration and washed thoroughly with methanol several times. After drying at $60{ }^{\circ} \mathrm{C}$ and $0.1 \mathrm{kPa}$ for $48 \mathrm{~h}$, the recycled catalyst was directly used for a consecutive run.
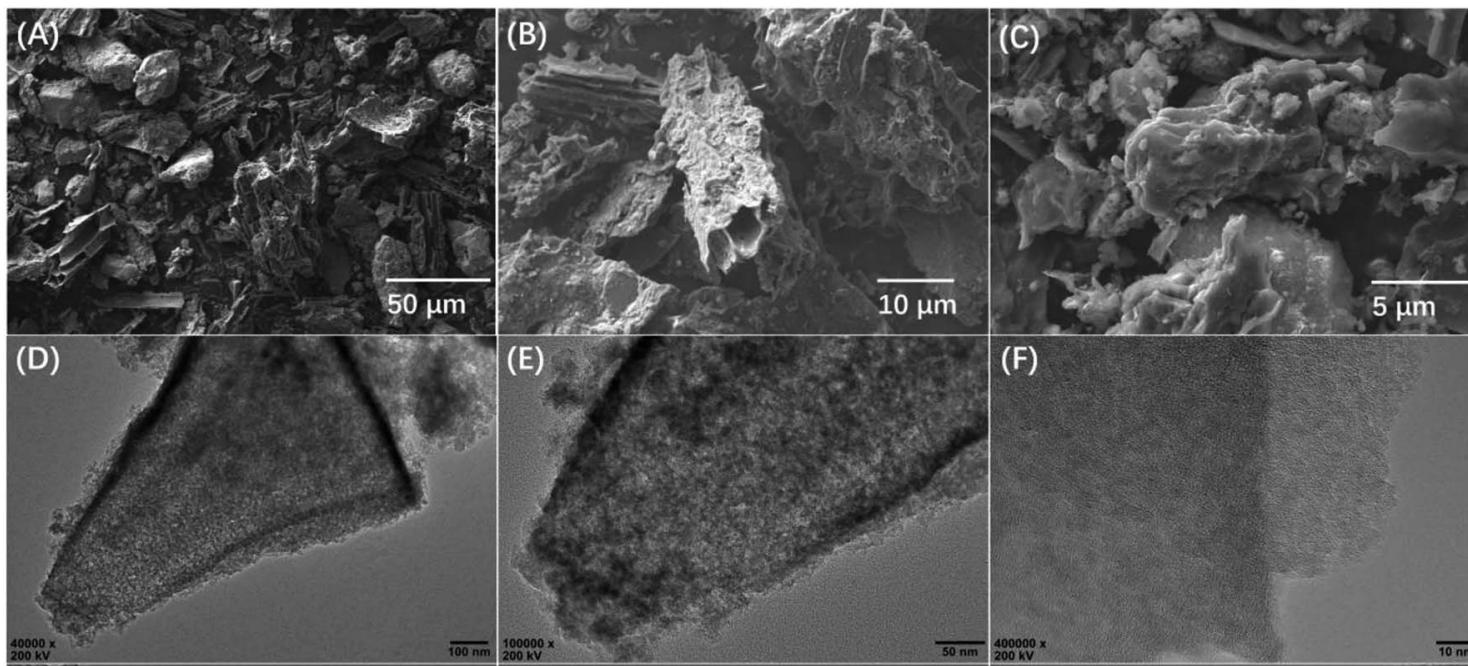

(F)
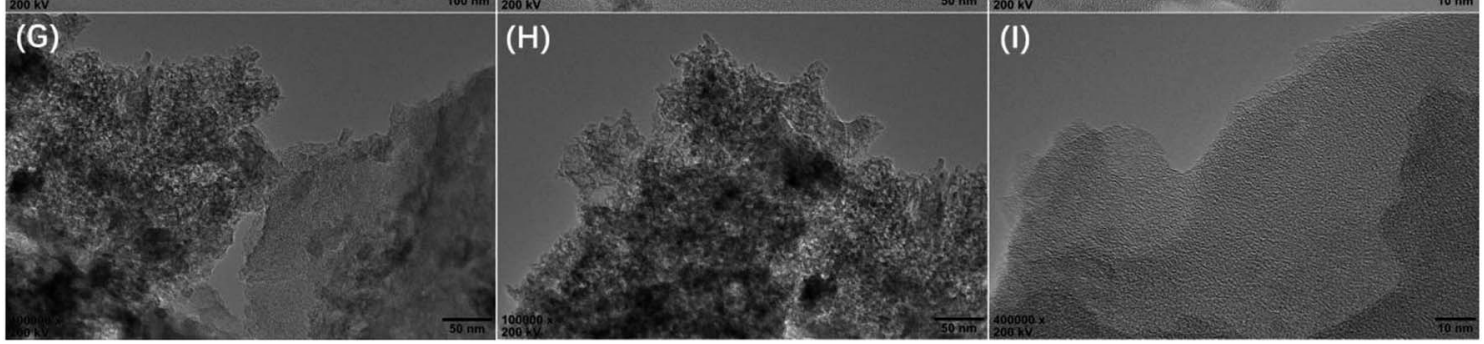

Fig. 2 SEM images of CMC (A), CMC-A-1 (B) and CMC-A-2 (C); TEM images of CMC-A-1 (D-F) and CMC-A-2 (G-I). 


\section{Results and discussion}

\subsection{Structural results}

The textural properties of the synthesized CMCs were determined using $\mathrm{N}_{2}$ as the probing gas. Fig. 1 shows the $\mathrm{N}_{2}$ adsorption isotherms at $-196{ }^{\circ} \mathrm{C}$ and pore size distributions of the CMCs. The $\mathrm{N}_{2}$ adsorption isotherms display type II profiles, with a significant increase in $\mathrm{N}_{2}$ uptake when the relative pressure approaches $1.0 .^{31}$ This result indicates the presence of combined micro-mesopores in the samples. ${ }^{32}$ The pore size distributions suggest disordered characteristics, with the $\mathrm{d} V / \mathrm{d} \log (W)$ pore volume covering a wide range of $0-15 \mathrm{~nm}$. The calculated textural properties are presented in Table S1. $\dagger$ It can be seen that the pristine CMC has poor porosity, with a specific surface area of 60 $\mathrm{m}^{2} \mathrm{~g}^{-1}$ and total pore volume of $0.05 \mathrm{~cm}^{3} \mathrm{~g}^{-1}$. However, the activated CMCs (CMC-A-1 and CMC-A-2) have significantly improved porosity, with the specific surface areas of 713 and 1106 $\mathrm{m}^{2} \mathrm{~g}^{-1}$ and total pore volumes of 0.56 and $0.93 \mathrm{~cm}^{3} \mathrm{~g}^{-1}$, respectively. Obviously, the ability of $\mathrm{NaNH}_{2}$ to activate pristine $\mathrm{CMC}$ is stronger than that of $\mathrm{KOH}$. The elemental analysis reveals that the pristine CMC contains $\sim 0.743 \mathrm{wt} \%$ of $\mathrm{N}$. However, the activated CMCs (CMC-A-1 and CMC-A-2) contain less N (0.369 and 0.391 wt $\%$, respectively). The change in $\mathrm{N}$ content suggests that some $\mathrm{N}$ species in pristine CMC are lost during the chemical activation process.
The morphology of the synthesized CMCs was examined by an electron microscope. Fig. 2 shows the SEM images of the CMCs and TEM images of the activated CMCs. The SEM images show the disordered shape and rough surface of CMCs. In the TEM images of the activated CMCs, a highly micro-mesoporous structure is observed, which is consistent with the textural properties calculated from the $\mathrm{N}_{2}$ adsorption isotherms.

The chemical structure of the synthesized CMCs was further characterized by X-ray powder diffraction and various kinds of spectroscopic methods. Fig. 3 shows the XRD patterns, Raman spectra and XPS spectra of the CMCs. In the XRD patterns, the pristine CMC displays the characteristic peaks of $\mathrm{CaCO}_{3}$, which is a component of cow manure; however, these peaks disappear after activation; this suggests that $\mathrm{CaCO}_{3}$ in the pristine $\mathrm{CMC}$ is converted to other non-crystalline $\mathrm{Ca}$ compounds during the chemical activation process. ${ }^{33}$ The XRD patterns of the activated CMCs display a weak and broad peak corresponding to the graphitic (002) plane at around $25.6^{\circ}$, suggesting the partially graphitized structure of the activated CMCs. ${ }^{34}$ In the Raman spectra, two peaks corresponding to the D and $\mathrm{G}$ bands are observed at around 1354 and $1587 \mathrm{~cm}^{-1}$. The $\mathrm{D}$ band associated with the $\mathrm{sp}^{3}$ carbon is weaker in intensity than the $\mathrm{G}$ band associated with $\mathrm{sp}^{2}$ carbon. ${ }^{35}$ Furthermore, the intensity ratio of the $\mathrm{D} / \mathrm{G}$ band does not show any obvious change after activation; this suggests that the defective structure of the pristine
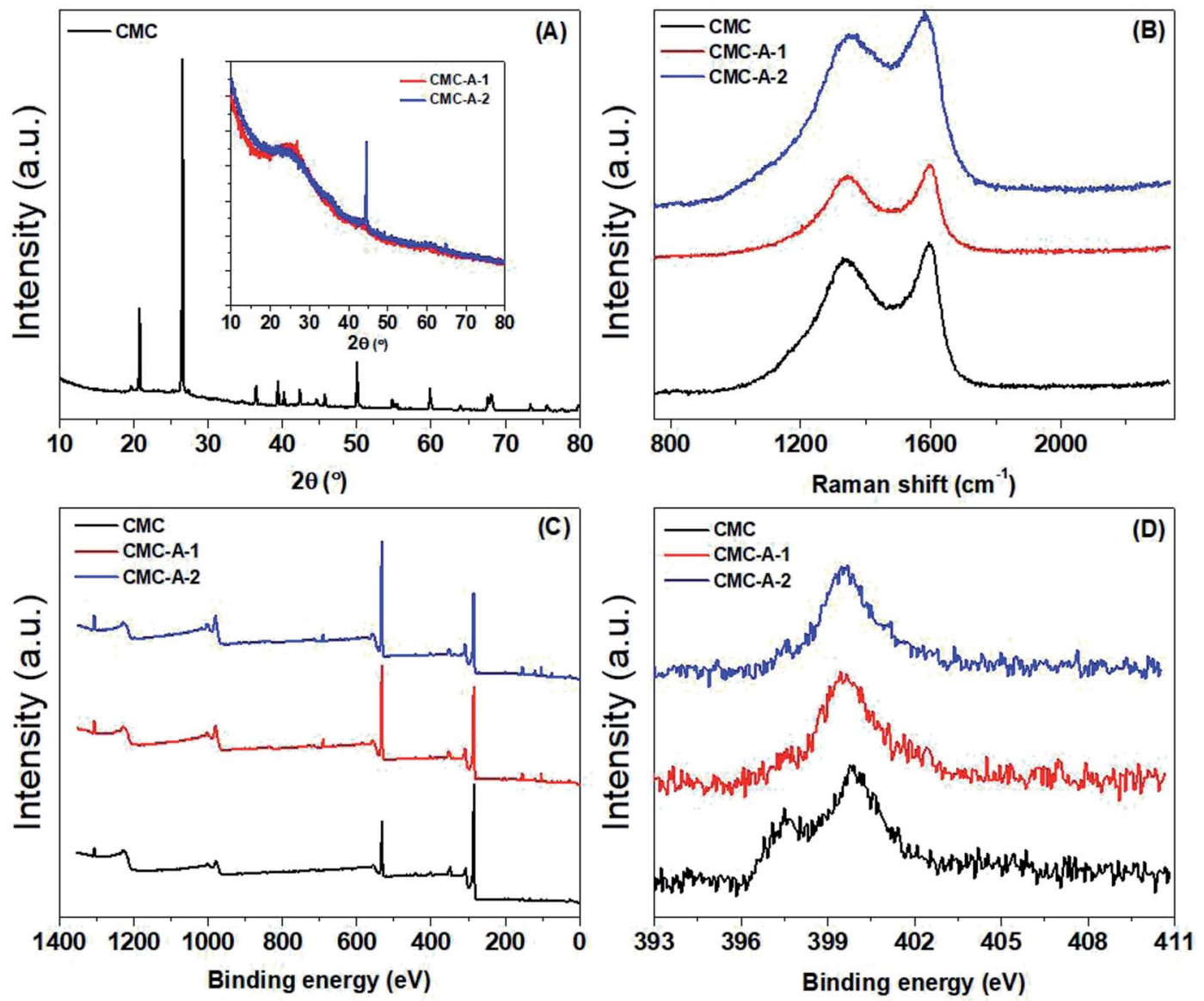

Fig. 3 XRD patterns (A), Raman spectra (B), full-range XPS survey (C) and N1s spectra (D) of CMCs. 
CMC does not change during the chemical activation process. ${ }^{36}$ In the full-range XPS survey, a series of peaks associated with C1s (284.16 eV, 73.29 at\%), O1s (531.34 eV, 16.4 at\%), N1s (399.70 eV, 2.50 at\%), Si2p (102.58 eV, 1.91 at\%), Ca2p (347.27 eV, 1.68 at\%), Al2p (74.06 eV, 1.27 at\%), P2p (132.91 eV, 1.18 at $\%)$ and Mg1s (1303.52 eV, 1.14 at\%) can be observed. The N1s spectra can be deconvoluted into two parts centered at 399.8 and $397.5 \mathrm{eV}$, corresponding to $\mathrm{N}$ in imine/amine/amide and pyridine, respectively. ${ }^{37}$ However, the percentage of pyridine is much higher in pristine CMC than that in the activated CMCs; this suggests that pyridine in the pristine CMC is lost during the chemical activation process. This is in agreement with the change in $\mathrm{N}$ content according to the elemental analysis.

\section{2 $\mathrm{CO}_{2}$ adsorption and conversion}

The $\mathrm{CO}_{2}$ capture performance of the synthesized CMCs was then investigated. Fig. 4 shows the $\mathrm{CO}_{2}$ and $\mathrm{N}_{2}$ adsorption isotherms of CMCs at 0 and $23{ }^{\circ} \mathrm{C}$. The $\mathrm{CO}_{2}$ capacities at 0.15 bar and IAST selectivities ${ }^{38}$ for a mixture of $\mathrm{CO}_{2}$ and $\mathrm{N}_{2}(0.15: 0.85 \mathrm{v} / \mathrm{v})$ at 1 bar are summarized in Table $\mathrm{S} 2, \uparrow$ which are relevant to the selective capture of $\mathrm{CO}_{2}$ from dilute sources (e.g., flue gas). It is found that the pristine $\mathrm{CMC}$ can adsorb only limited amount of $\mathrm{CO}_{2}$ $\left(0.51 \mathrm{mmol} \mathrm{g}^{-1}\right.$ at $0{ }^{\circ} \mathrm{C}$ and $0.41 \mathrm{mmol} \mathrm{g}^{-1}$ at $23^{\circ} \mathrm{C}$ ) because of its poor porosity; however, the activated CMCs can adsorb much more $\mathrm{CO}_{2}\left(0.81 \mathrm{mmol} \mathrm{g}^{-1}\right.$ at $0{ }^{\circ} \mathrm{C}$ and $0.63 \mathrm{mmol} \mathrm{g}^{-1}$ at $23{ }^{\circ} \mathrm{C}$ for CMC-A-1, $1.44 \mathrm{mmol} \mathrm{g}^{-1}$ at $0{ }^{\circ} \mathrm{C}$ and $0.73 \mathrm{mmol} \mathrm{g}^{-1}$ at $23{ }^{\circ} \mathrm{C}$ for
CMC-A-2) owing to their significantly improved porosity. ${ }^{39}$ The sequence of $\mathrm{CO}_{2}$ capacities is consistent with the sequence of the specific surface areas (CMC-A-2 > CMC-A-1 > CMC). The $\mathrm{CO}_{2}$ capacities of CMC-A-2 are comparable to or higher than those of many other porous carbon materials reported in the literature. ${ }^{\mathbf{4 0}}$ The $\mathrm{N}_{2}$ capacities are a magnitude lower than the $\mathrm{CO}_{2}$ capacities. The $\mathrm{CO}_{2} / \mathrm{N}_{2}$ selectivities of the CMCs are in the range of 14.9-51.0 at $0{ }^{\circ} \mathrm{C}$ and $21.1-41.4$ at $23{ }^{\circ} \mathrm{C}$. The sequence of $\mathrm{CO}_{2} / \mathrm{N}_{2}$ selectivities is also well consistent with the sequence of the specific surface areas (CMC-A-2 > CMC-A-1 > CMC). This can be explained by the fact that the chemical activation process introduces significant micropores, which enable the size sieving of $\mathrm{CO}_{2}$ against $\mathrm{N}_{2} \cdot{ }^{41}$ As a result, the activated CMCs display highly efficient and selective capture of $\mathrm{CO}_{2}$.

The cycling property of CMCs in the $\mathrm{CO}_{2}$ capture was also an important factor for their practical applications. Fig. $\mathrm{S} 1 \dagger$ depicts the cycling property of CMC-A-2 in the capture of $\mathrm{CO}_{2}$ at $23{ }^{\circ} \mathrm{C}$. Notably, the absorbed $\mathrm{CO}_{2}$ could be completely released after treating CMC-A-2 with $\mathrm{N}_{2}$ at $75{ }^{\circ} \mathrm{C}$, and the regenerated CMC-A-2 was directly used for the next run. The $\mathrm{CO}_{2}$ capacities of CMC-A2 did not decrease after 8 cycles, and the capacities of the fresh and regenerated $\mathrm{CMC}-\mathrm{A}-2$ for $\mathrm{CO}_{2}$ were around $1.5 \mathrm{mmol} \mathrm{g}^{-1}$. This result is well consistent with the results obtained from the $\mathrm{CO}_{2}$ isotherms. The abovementioned results confirm very good stability of CMCs for the selective capture of $\mathrm{CO}_{2}$.

The activated CMCs were finally supported with metal ions and used as heterogeneous catalysts for $\mathrm{CO}_{2}$ conversion. The cycloaddition of $\mathrm{CO}_{2}$ to $\mathrm{PO}$ was used as the model reaction.
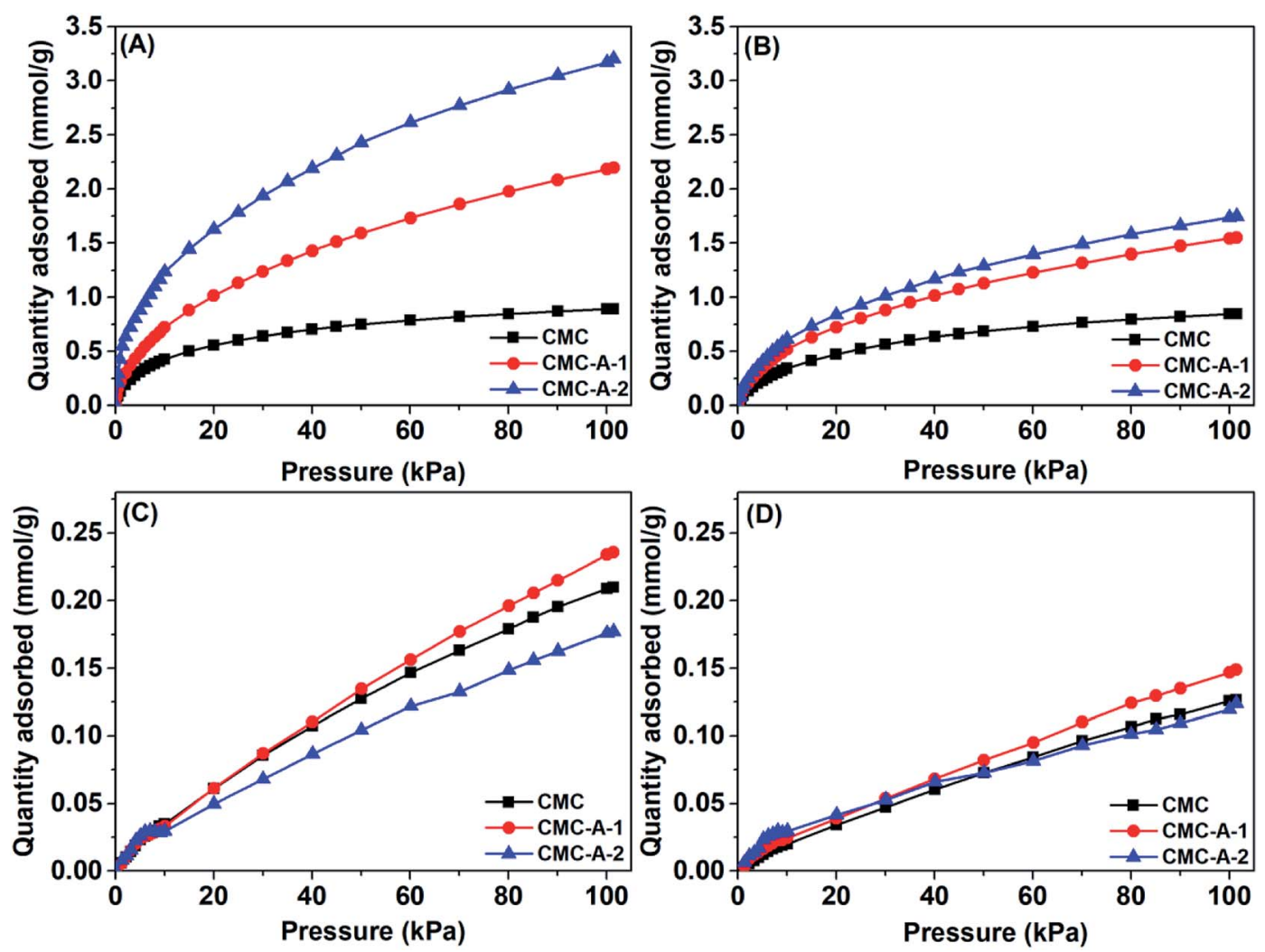

Fig. $4 \mathrm{CO}_{2}(\mathrm{~A}$ and $\mathrm{B})$ and $\mathrm{N}_{2}(\mathrm{C}$ and $\mathrm{D})$ adsorption isotherms of $\mathrm{CMCs}$ at $0{ }^{\circ} \mathrm{C}(\mathrm{A}$ and $\mathrm{C})$ and $23^{\circ} \mathrm{C}(\mathrm{B}$ and $\mathrm{D})$. 
Table 1 Cycloaddition of $\mathrm{CO}_{2}$ to propylene oxide catalyzed by $\mathrm{CMCs}^{a}$

\begin{tabular}{|c|c|c|c|c|c|c|}
\hline Entry & Catalysts & Metal contents ${ }^{b}\left(\mathrm{mmol} \mathrm{g}^{-1}\right)$ & Additive & Yields (\%) & Selectivities & TOFs $\left(h^{-1}\right)$ \\
\hline 1 & Co/CMC-A-1 & 0.60 & ТВAB & 95 & $\sim 100$ & 701 \\
\hline 2 & Co/CMC-A-2 & 0.61 & TBAB & 95 & $\sim 100$ & 695 \\
\hline 4 & $\mathrm{Co} / \mathrm{CMC}-\mathrm{A}-1$ & 0.60 & None & 26 & $\sim 100$ & 195 \\
\hline 5 & None & - & TBAB & 36 & $\sim 100$ & - \\
\hline 6 & CMC-A-1 & - & TBAB & 42 & $\sim 100$ & - \\
\hline 9 & $\mathrm{Co} / \mathrm{CMC}-\mathrm{A}-1^{e}$ & 0.60 & TBAB & 92 & 99 & 21 \\
\hline
\end{tabular}

${ }^{a}$ Reaction conditions: propylene oxide $(20 \mathrm{mmol})$, TBAB $(7.2 \mathrm{~mol} \%)$, catalyst $(30 \mathrm{mg}), \mathrm{CO}_{2}(0.5 \mathrm{MPa})$, temperature $\left(100{ }^{\circ} \mathrm{C}\right)$, time $(1.5 \mathrm{~h})$.

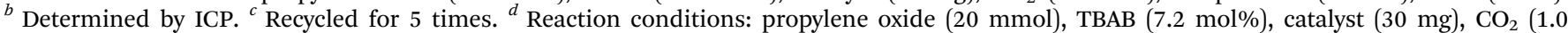
$\mathrm{MPa})$, temperature $\left(100{ }^{\circ} \mathrm{C}\right)$, time $(0.5 \mathrm{~h}) .{ }^{e}$ Reaction conditions: propylene oxide $(20 \mathrm{mmol}), \mathrm{TBAB}(7.2 \mathrm{~mol} \%)$, catalyst $(30 \mathrm{mg}), \mathrm{CO}_{2}(0.5 \mathrm{MPa})$, temperature $\left(25^{\circ} \mathrm{C}\right)$, time $(48 \mathrm{~h})$.

Table 2 Co/CMC-A-1 catalyzed the cycloaddition reactions of epoxides with $\mathrm{CO}_{2}$ to cyclic carbonates ${ }^{a}$
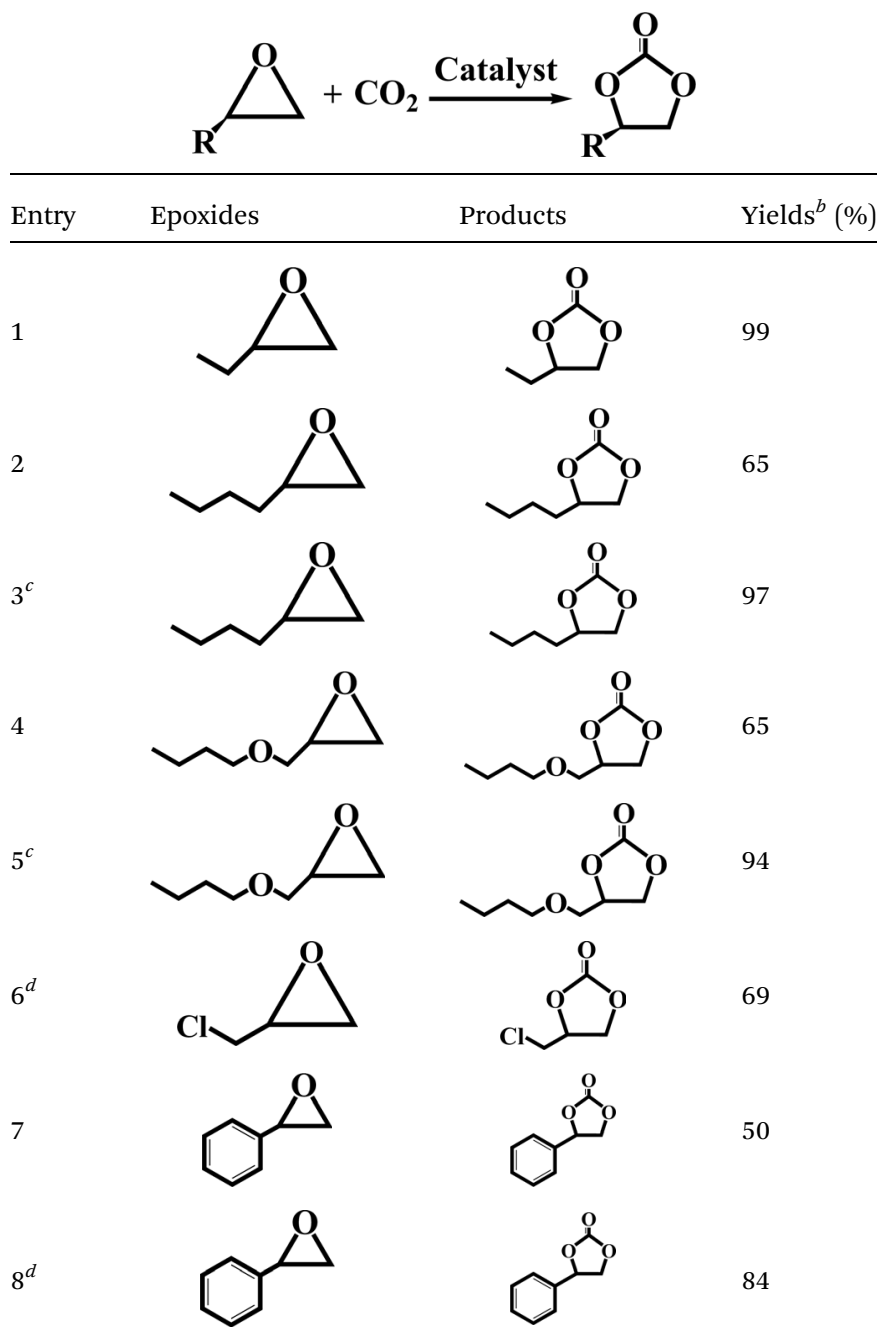

${ }^{a}$ Condition: epoxides (10 mmol), Co/CMC-A-1 (0.5 mol\%), TBAB $(7 \mathrm{~mol} \%), \mathrm{CO}_{2}(1.0 \mathrm{~atm}), \mathrm{RT}\left(\mathrm{ca} .30{ }^{\circ} \mathrm{C}\right)$, and $48 \mathrm{~h} .{ }^{b}$ The yields were determined by GC-MAS. ${ }^{c} 50{ }^{\circ} \mathrm{C}$ for $48 \mathrm{~h} .{ }^{d} 80^{\circ} \mathrm{C}$ for $48 \mathrm{~h}$.
Table 1 lists the yields, selectivities and TOFs of the activated CMC-based catalysts for the cycloaddition of $\mathrm{CO}_{2}$ to $\mathrm{PO}$ under different reaction conditions. As can be seen, Co/CMC-A-1 and Co/CMC-A-2 display comparable performances in the catalytic conversion of $\mathrm{CO}_{2}$, with yields of $>95 \%$, selectivities of $>99 \%$ and TOFs of $\sim 700 \mathrm{~h}^{-1}$ at $100{ }^{\circ} \mathrm{C}$ and $0.5 \mathrm{MPa}$ for $1.5 \mathrm{~h}$ (entries 1 and 2). If the loaded $\mathrm{Co}^{2+}$ is changed to $\mathrm{Zn}^{2+}$, the resultant $\mathrm{Zn} / \mathrm{CMC}-\mathrm{A}$ 1 displays comparable performance to $\mathrm{Co} / \mathrm{CMC}-\mathrm{A}-1$ for the catalytic conversion of $\mathrm{CO}_{2}$ (entry 3 ). However, the yields decreased to $<50 \%$ if no TBAB, catalyst or metal ions were used (entries 4-6); this suggested the essential roles of the three components in catalyzing the conversion of $\mathrm{CO}_{2}$. Even after being recycled for 5 times, Co/CMC-A-1 still displayed the yield of 95\%, selectivity of $99 \%$ and TOF of $719 \mathrm{~h}^{-1}$ (entry 7), comparable to those of the fresh catalyst. This result confirms the high stability of the activated CMC-based catalysts during recycling. The performance of Co/CMC-A-1 for catalyzing the conversion of $\mathrm{CO}_{2}$ at an elevated pressure of 1.0 MPa for a shortened time of $0.5 \mathrm{~h}$ (entry 8) or at a room temperature of $25^{\circ} \mathrm{C}$ for a long time of $24 \mathrm{~h}$ (entry 9) was also investigated. It is found that the temperature has a significant effect on the activity of $\mathrm{Co} / \mathrm{CMC}-\mathrm{A}-1$ for the catalytic conversion of $\mathrm{CO}_{2}$, and a higher temperature is preferred for facilitating the conversion of $\mathrm{CO}_{2}$. Overall, the performance of the activated CMC-based catalysts for the catalytic conversion of $\mathrm{CO}_{2}$ is comparable or superior to that of most other heterogeneous catalysts reported in Table $\mathrm{S} 3 \dagger$ and the literature. ${ }^{\mathbf{2 0 , 4 2 , 4 3}}$ Furthermore, the Co/CMC-A-1 catalyst showed good effect for the cycloaddition of epoxides and $\mathrm{CO}_{2}$ to cyclic carbonates, and the results can be found in the Table 2 .

\section{Conclusions}

In summary, cow manure obtained from local farms was used as a precursor for the synthesis of porous carbon materials by direct carbonization followed by chemical activation. The chemical activation by $\mathrm{KOH}$ and $\mathrm{NaNH}_{2}$ significantly improved the porosity of cow manure-derived carbons. Electron microscopy and spectroscopic characterizations demonstrated the amorphous and disordered structure of the cow manure- 
derived carbons. The synthesized cow manure-derived carbons were used as heterogenous catalysts for $\mathrm{CO}_{2}$ conversion. It was found that the cow manure-derived carbons displayed competitive performance for the selective capture and catalytic conversion of $\mathrm{CO}_{2}$. The present study provides an alternative method for the preparation of heterogeneous catalysts for $\mathrm{CO}_{2}$ conversion from abundant bio-waste.

\section{Conflicts of interest}

There are no conflicts to declare.

\section{Acknowledgements}

This work was supported by the National Natural Science Foundation of China (21573150).

\section{References}

1 S. Asefi-Najafabady, P. J. Rayner, K. R. Gurney, A. McRobert, Y. Song, K. Coltin, J. Huang, C. Elvidge and K. Baugh, J. Geophys. Res.: Atmos., 2014, 119, 10213-10231.

2 J. X. Mi, Y. N. Cao, J. C. Zhang, Y. D. Ma, C. Q. Chen, D. L. Li, X. Y. Lin and L. L. Jiang, Appl. Catal., A, 2018, 553, 36-42.

3 P. M. Cox, R. A. Betts, C. D. Jones, S. A. Spall and I. J. Totterdell, Nature, 2000, 408, 750.

4 T. L. Johnson and D. W. Keith, Energy Policy, 2004, 32, 367382.

5 F. J. Liu, K. Huang, S. M. Ding and S. Dai, J. Mater. Chem. A, 2016, 4, 14567-14571.

6 Y. Zhang and D. S. Lim, ChemSusChem, 2015, 8, 2606-2608.

7 Q. W. Song, Z. H. Zhou and L. N. He, Green Chem., 2017, 19, 3707-3728.

8 F. J. Liu, K. Huang, Q. Wu and S. Dai, Adv. Mater., 2017, 29, 1700445.

9 R. L. Paddock and S. T. Nguyen, J. Am. Chem. Soc., 2001, 123, 11498-11499.

10 K. Chen, G. Shi, W. Zhang, H. Li and C. Wang, J. Am. Chem. Soc., 2016, 138, 14198-14201.

11 F. Huang, G. Lu, L. Zhao, H. Li and Z. X. Wang, J. Am. Chem. Soc., 2010, 132, 12388-12396.

12 Z. Z. Yang, L. N. He, Y. N. Zhao, B. Li and B. Yu, Energy Environ. Sci., 2011, 4, 3971-3975.

13 C. M. Momming, E. Otten, G. Kehr, R. Frohlich, S. Grimme, D. W. Stephan and G. Erker, Angew. Chem., Int. Ed., 2009, 48, 6643-6646.

14 X. Ma, B. Zou, M. Cao, S. L. Chen and C. Hu, J. Mater. Chem. A, 2014, 2, 18360-18366.

15 Y. Li, B. Zou, C. Hu and M. Cao, Carbon, 2016, 99, 79-89.

16 K. Huang, J. Y. Zhang, F. J. Liu and S. Dai, ACS Catal., 2018, 8, 9079-9102.

17 S. W. Xu, Y. Lu, J. Li, Z. Y. Jiang and H. Wu, Ind. Eng. Chem. Res., 2006, 45, 4567-4573.

18 A. Zhu, T. Jiang, B. Han, J. Zhang, Y. Xie and X. Ma, Green Chem., 2007, 9, 169-172.
19 L. Liang, C. Liu, F. Jiang, Q. Chen, L. Zhang, H. Xue, H. L. Jiang, J. Qian, D. Yuan and M. Hong, Nat. Commun., 2017, 8, 1233.

20 G. Ji, Z. Z. Yang, H. Zhang, Y. Zhao, B. Yu, Z. Ma and Z. M. Liu, Angew. Chem., Int. Ed., 2016, 55, 9685-9689.

21 K. Huang, F. J. Liu, L. L. Jiang and S. Dai, ChemSusChem, 2017, 10, 4144-4149.

22 K. Huang, F. J. Liu and S. Dai, J. Mater. Chem. A, 2016, 4, 13063-13070.

23 J. Liu, N. P. Wickramaratne, S. Z. Qiao and M. Jaroniec, Nat. Mater., 2015, 14, 763-774.

24 H.-L. Peng, J.-B. Zhang, J.-Y. Zhang, F.-Y. Zhong, P.-K. Wu, K. Huang, J.-P. Fan and F. J. Liu, Chem. Eng. J., 2019, 359, 1159-1165.

25 M. Titirici and M. Antonietti, Chem. Soc. Rev., 2010, 39, 103116.

26 W. Z. Zhong, Z. Z. Zhang, Y. J. Luo, W. Qiao, M. Xiao and M. Zhang, Bioresour. Technol., 2012, 114, 281-286.

27 M. Titirici, R. J. White, N. Brun, V. L. Budarin, D. S. Su, F. del Monte and J. H. Clark, Chem. Soc. Rev., 2015, 44, 250-290.

28 M. Biswal, A. Banerjee, M. Deo and S. Ogale, Energy Environ. Sci., 2013, 6, 1249-1259.

29 C. D. do E. S. Barbosa, J. Corrêa, G. A. Medeiros, G. Barreto, K. G. Magalhaes, A. L. de Oliveira, J. Spencer, M. O. Rodrigues and B. A. D. Neto, Chem.-Eur. J., 2015, 21, 5055-5060.

30 I. Noshadi, B. Kanjilal and F. J. Liu, Appl. Catal., A, 2016, 513, 19-29.

31 K. Ramesh, K. S. Reddy, I. Rashmi, A. K. Biswas and K. R. Islam, Commun. Soil Sci. Plant Anal., 2016, 47, 16221629.

32 F. J. Liu, L. Wang, Q. Sun, L. F. Zhu, X. J. Meng and F.-S. Xiao, J. Am. Chem. Soc., 2012, 134, 16948-16950.

33 Y. Y. Lv, F. Zhang, Y. Q. Dou, Y. P. Zhai, J. X. Wang, H. J. Liu, Y. Y. Xia, B. Tua and D. Y. Zhao, J. Mater. Chem., 2012, 22, 9399.

34 B. He, F. J. Liu and S. K. Yan, J. Mater. Chem. A, 2017, 5, 18064-18070.

35 K. Huang, F. J. Liu, J.-P. Fan and S. Dai, ACS Appl. Mater. Interfaces, 2018, 10, 36961-36968.

36 J. Xu, M. Wang, N. P. Wickramaratne, M. Jaroniec, S. Dou and L. Dai, Adv. Mater., 2015, 27, 2042-2048.

37 K.-Y. Park, J.-H. Jang, J.-E. Hong and Y.-U. Kwon, J. Phys. Chem. C, 2012, 116, 16848-16853.

38 A. L. Myers and J. M. Prausnitz, AIChE J., 1965, 11, 121-127. 39 J. W. F. To, J. J. He, J. G. Mei, R. Haghpanah, Z. Chen, T. Kurosawa, S. C. Chen, W.-G. Bae, L. J. Pan, J. B.-H. Tok, J. Wilcox and Z. N. Bao, J. Am. Chem. Soc., 2016, 138, 10011009.

40 A. E. Creamer and B. Gao, Environ. Sci. Technol., 2016, 50, 7276-7289.

41 K. C. Bedin, A. C. Martins, A. L. Cazetta, O. Pezoti and V. C. Almeida, Chem. Eng. J., 2016, 286, 476-484.

42 Y. Xie, T. T. Wang, X. H. Liu, K. Zou and W. Q. Deng, Nat. Commun., 2013, 4, 1960.

43 A. P. Katsoulidis and M. G. Kanatzidis, Chem. Mater., 2011, 23, 1818-7289. 